\title{
POST PROJECT ENVIRONMENTAL MONITORING AND IMPACT ASSESSMENT - A CASE OF GOKARNA SANITARY LANDFILL SITE AFTER OPERATION AND CLOSURE
}

\author{
Sudarshan Chandra Khanal \\ Central Department of Environmental Science, Tribhuvan University, Kathmandu, Nepal.
}

\begin{abstract}
Environmental Assessment (EA) is the identification, prediction and evaluation of Environmental impacts. Environmental Monitoring transforms EA from a one time pre-project document to a continual assessment of impacts. Post project analysis concerns life cycle environmental management and environmental studies during project implementation. This study illustrates significance of Post project Environmental Monitoring and Impact Assessment using a factual example of Gokarna Sanitary Landfill Site (GLFS) after final operation and closure. The environmental inventory, the preventive and compensatory measures adopted by GLFS were studied and some modes of public involvement, economic measures and regulatory measures were analyzed during the construction and operation of the GLFS. Environmental inventory of the site indicated that GLFS might constitute concrete environmental conflict. The result of handpicking analysis showed that risk of medical and industrial hazardous waste cannot be excluded. Water and leachate analysis indicated that the impact of disposal is still pronounced at the site and ground water pollution may be dispersing to the general ground water flow direction. Soil analysis indicated that impact of disposal is pronounced on similar trends in two sites in landfill site. $\mathrm{PH}, \mathrm{BOD}$ and $\mathrm{COD}$ values of leachate indicated that a good biodegradation of organic wastes (i.e. stable methane process) is going on the site and opens a potential for using landfill gas as an energy resource. The public participation, and economic measures studied through questionnaire method confirmed that during operation phase there was inadequate compliance with the planning and operational strategies at implementation that is also a major issue environmentally. There were no provisions for monitoring hazardous wastes, surface and ground water pollution and landfill gas during the operation phase. This study intends to conclude for regular Environmental Monitoring and Post project Impact Assessment for corrective actions and also for the construction and successful operation of similar projects. Possibility of Post project Environmental Monitoring and Impact Assessment in environmental policy making is also considered.
\end{abstract}

Key words: Environmental monitoring; Environmental assessment; Post project analysis; Impact assessment; GLFS.

\section{INTRODUCTION}

Environmental monitoring refers to the set of activities that provide chemical, physical, geological, biological and environmental, social, or health data required by environmental managers (USEPA, 1986). Environmental monitoring involves the systematic collection of data to determine: 1) the actual environmental effects of a project; 2) the compliance of the project with regulatory standards; or 3) the degree of implementation of environmental protection measures and success of the environmental protection measures. When successfully integrated with the environmental management system for the project, environmental monitoring can provide valuable feedback about the effectiveness of environment protection measures and in turn monitoring may be related to the post project analysis (Shephard, 1994). Post project analysis concerns life cycle environmental management and environmental studies during project implementation (ECE, 1990). Post project analysis is essential to check the implementation of mitigation measures, to provide early warning of potential environmental damage, to audit mitigation measures, to refine assessment methods, to improve project outcomes through adaptive environmental management (Shephard, 1994). Many post project impacts may be anticipated and the agency may continually adopt, evaluate and improve impact management activities.

Despite its widely recognized importance, monitoring is not a well established activity for several reasons: Environmental monitoring data are expensive and difficult to collect; monitoring can be time consuming; agencies lack guidance and are under little legal pressure to conduct monitoring; agencies may fear self-incrimination through monitoring. However, lack of appropriate monitoring impedes scientific progress in impact prediction and assessment and makes it difficult to learn from experience (Khadka, 1996).

Development projects directed at improving levels of material comfort with inadequate environmental planning, have had unintended detrimental effect on people and natural resources (Lohani et al., 1997). However increasing economic development, correlating with technological progress will often reduce the environmental damage (Radetzki, 1992); but this relation between environmental quality and economic 
Table 1: Various measures to minimize NIMBY ${ }^{4}$ opposition during landfill site operation.

\begin{tabular}{|l|l|l|}
\hline $\begin{array}{l}\text { Measures to minimize } \\
\text { NIMBY opposition }\end{array}$ & Institutional requirement & Example \\
\hline Public Participation & $\begin{array}{l}\text { Mutual respect, understanding and co-operation } \\
\text { with the community opinion A }\end{array}$ & $\begin{array}{l}\text { Active public participation, } \\
\text { collaborative decision making }\end{array}$ \\
\hline Economic Measures & $\begin{array}{l}\text { Minimum compensation sum to the potential host } \\
\text { Economic measures to reduce the waste production }\end{array}$ & $\begin{array}{l}\text { Differential disposal fee } \\
\text { buffer zones }\end{array}$ \\
\hline Regulatory Measures & $\begin{array}{l}\text { Establishment of comprehensive control } \\
\text { mechanism }^{\text {C }}\end{array}$ & site, provision of \\
\hline
\end{tabular}

A. Shield (1990), B. Quah and Tan (1996), C. GTZ (1996).

development often proposed to the extension of Environmental Kuznets Curve (EKC) ${ }^{1}$ is invalid for consumption based pollution ( $\mathrm{CO}_{2}$ and municipal solid waste) (Rothman, 1998). In addition, Shafik (1994), using data from 149 countries, showed that environmental indicators as carbon emissions, municipal wastes and dissolved oxygen deteriorate steadily with increase in economic development.

Managing solid waste in the developing countries like Nepal, the effective method of waste disposal is the landfill. The waste composition ${ }^{2}$, high cost and the technical difficulties of operation makes the incineration inappropriate for reducing the amount of materials (Oeltzschner and Mutz, 1994), which finally will have to be disposed to the landfill.

Landfill facilities on the one hand are necessary for the community and are useful to the general public, whereas, on the other hand, environmental impacts associated with the landfill sites during the operational and even post-operational phase makes the facility sensitive from the environmental view. Due to the negative externalities ${ }^{3}$ arising from a landfill site, people living within the community oppose the landfill.

Table 2: Environmental Impact of GLFS during operational phase by rank.

\begin{tabular}{|c|l|}
\hline 1 & Air Quality (Air pollution and bad odor) \\
\hline 2 & Bird Problem \\
\hline 3 & Vermin Problem \\
\hline 4 & Noise Pollution \\
\hline 5 & Other (Visual intrusion, water quality) \\
\hline
\end{tabular}

The table is based on the interview with the local people during field visit.

Table 3: High possibility of hazardous contents of a landfill site.

\begin{tabular}{|l|l|}
\hline 1 & Hazardous leaching \\
\hline 2 & Gaseous emissions \\
\hline 3 & Soil pollution \\
\hline
\end{tabular}

Parameters adapted from checklist for the evaluation of the 'hazard potential' of a dump site (Oeltzschner and Mutz, 1994) pp. 63.
That this type of public opposition is expected to accelerate; various international bodies have suggested on further steps that might be taken towards dialogue and partnership (Munn et al, 1996). The reuse and sharing of assessment data should be encouraged for fulfilling the impact assessment method (Shephard, 1994). (Table 1)

Gokarna Landfill Site (GLFS) was developed and operated since 1986 as the final disposal site of solid waste of Kathmandu and Lalitpur Municipalities. Till 1990 it was operated with stringent management practices and prolonged haphazardly till January 1994. Public opposition due to insufficient management was a major concern during the operation of GLFS. The landfill site was finally closed in 2000. The mistake was then realized that the socio-environmental aspects were not properly taken into consideration during GLFS project cycle (Oeltzschner and Kharel, 1997). (Table 2 \&3)

\section{METHODS AND DATA}

The study was based on the assessment of environmental factors to diagnose the state of the system for finding the environmental condition or the trend and determine the potential environmental risk of the landfill. The research was further extended to analyze the GLFS Project activities in terms of monitoring and other activities performed by GLFS to reduce the public opposition. The results were finally analyzed in order to consider environmental monitoring in environmental management, and thereby expanding the scope of monitoring.

\subsection{Post closure environmental inventory}

Environmental inventory was split into different environmental aspects such as waste, gas, leachate, and groundwater as per Hogland (1989). The inventory of environmental factors included handpicking analysis of waste, physico-chemical analysis (methods prescribed by APHA,1998) of leachate and groundwater around GLFS, physico-chemical analysis (methods described by Trivedy

\footnotetext{
1 The environmental Kuznets curve (EKC), or inverted U-shape relation between environment and income suggests that environmental damage increases at lower income levels, reaches a maximum level and declines thereafter.

2 Composition of waste includes higher humidity and low calorific value.

3 Bad effects that are often characterized by the facility's impact on health, property prices, noise and air pollution, community disgrace, loss of amenities and negative visual impacts.

4 The wide-spread public 'Not In My Back Yard (NIMBY) opposition' started in USA in 1970s to oppose the landfill site around their vicinity.
} 
\& Goel, 1984), grain size analysis (methods prescribed by ASTM standards, 1986) of soil in and around GLFS and a general survey of the landfill gas around GLFS. Furthermore, a survey of geo-hydrological conditions and the sensitivity of groundwater toward pollution was carried out as there was no sufficient liner laid during operation phase.

\subsection{GLFS Project activities}

Two sets of questionnaire patterns ${ }^{5}$ were developed for household survey ${ }^{6}$ and for key informants ${ }^{7}$. The questionnaire design phase involved selection of attributes after field visit, group discussion with local people and interview with potential key informants.

\section{RESULTS}

\subsection{Post closure environmental inventory}

Figure 1 show the waste composition landfilled at GLFS. During excavation of the waste landfilled at GLFS, certain materials as textiles, plastic bags, shoes, plastic-bottles, traces of medical wastes (syringes and drug bottles), batteries, construction materials, tires, packages, paint tubes, old pens and aluminum cans were observed. Presence of traces of medical wastes, unmanufactured leather products, batteries, paint tubes and aluminum cans showed that the risk of medical and industrial wastes could not be eliminated.

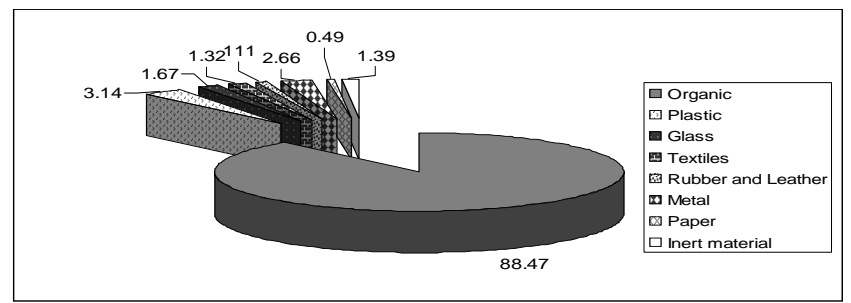

Fig.1: Results from the handpicking analysis at GLFS (values in percentage).

Table 4 shows the comparative analysis of water samples taken form four sampling sites. In figures 2, 3 and 4 chemical parameters of the leachate (i.e. sample from channeling pipe) are compared. The reduction of the chemical parameters in leachate from that of AIT (1998) and NESS (1996), and increase in pollution parameters downstream relative to upstream the landfill site may be related to the ground water flow direction. Seepage of leachate outward the adjoining hill, northeastern the landfill site may relate the leachate flow direction, which

Table 4: Comparison of water quality parameters.

\begin{tabular}{|c|c|c|c|c|}
\hline \multirow{2}{*}{ Parameters } & \multicolumn{2}{|c|}{ Leachate } & \multicolumn{2}{|c|}{ Tap } \\
\hline & Channeling pipe & Surface drain & Upstream & Downstream \\
\hline $\mathrm{P}^{\mathrm{H}}$ & 6.7 & 5.6 & 6.2 & 5.9 \\
\hline Electrical Conductivity( $\mu$ s) & 547 & 95.9 & 86.7 & 439 \\
\hline \multicolumn{5}{|c|}{ INORGANIC COMPONENTS } \\
\hline Alkalinity as $\mathrm{CaCO}_{3}(\mathrm{mg} / \mathrm{l})$ & 570 & 40 & 300 & 180 \\
\hline Hardness as $\mathrm{CaCO}_{3}(\mathrm{mg} / \mathrm{l})$ & 424 & 156 & 30 & 16 \\
\hline Calcium(mg/l) & 12.024 & 13.627 & 3.2 & 5.6112 \\
\hline Magnesium(mg/l) & 24.364 & 30.532 & 0.969 & 0.484 \\
\hline $\operatorname{Iron}(\mathrm{mg} / \mathrm{l})$ & 10.8 & 4.64 & 0.31 & 0.45 \\
\hline Nitrate(mg/l) & 3.57 & ND & ND & 0.88 \\
\hline Chloride(mg/l) & 134.90 & 17.04 & 29.82 & 59.64 \\
\hline Phosphate(mg/l) & 2.85 & 0.06 & 0.09 & 0.11 \\
\hline Ammonia-N(mg/l) & 0.051 & $<0.01$ & $<0.01$ & $<0.01$ \\
\hline Dissolved Oxygen(mg/l) & 2.432 & 4.864 & 3.243 & 4.054 \\
\hline Free $\mathrm{CO}_{2}(\mathrm{mg} / \mathrm{l})$ & 198 & 704 & 264 & 880 \\
\hline Chromium(mg/l) & 0.01 & ND & ND & ND \\
\hline Nickel(mg/l) & 0.03 & ND & ND & ND \\
\hline Copper(mg/l) & 0.06 & ND & 0.02 & 0.05 \\
\hline \multicolumn{5}{|l|}{ ORGANIC COMPONENTS } \\
\hline BOD & 75.674 & 64.864 & 8.108 & 40.54 \\
\hline COD & 567.666 & 195 & 150.3 & 120 \\
\hline
\end{tabular}

ND: Not Detected.

5 Copies are available upon request.

6 Rushbrook (1985) listed the number of people questioned in the range of $10 \%$ to $25 \%$ of the affected family for scoping Environment Impact Assessment (EIA) of municipal solid waste landfill. 40 households (15.9\% of the total households) were considered by taking 25 households (16.2\% of the households) within distance range $0-500 \mathrm{~m}$ and 15 households ( $15.3 \%$ of the households) within distance range 500-1000m.

7 Key informants were selected by purposive sampling according to their experience in the field of solid waste management. 
is also the general ground flow direction of Kathmandu Valley as per Dhaubhadel (1988) who determined the general ground water flow direction of unconfined aquifer going to the direction of the center of the Kathmandu basin.

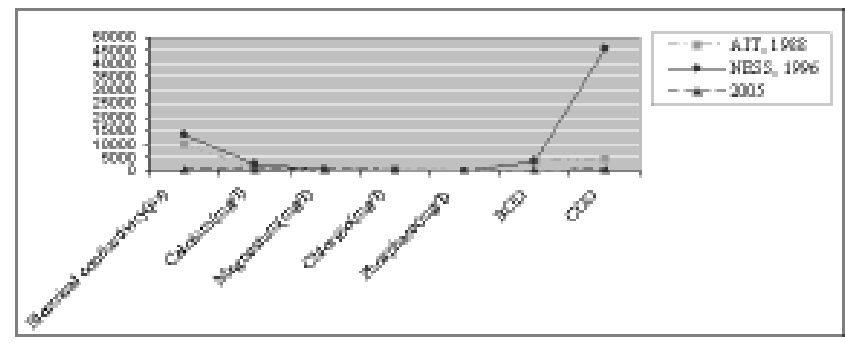

Fig 2: Comparison of chemical parameters in leachate.

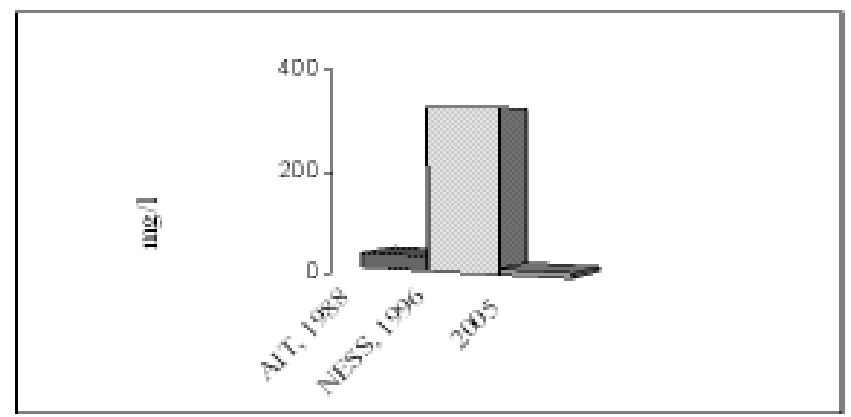

Fig 3: Comparison of iron (mg/l) in leachate.

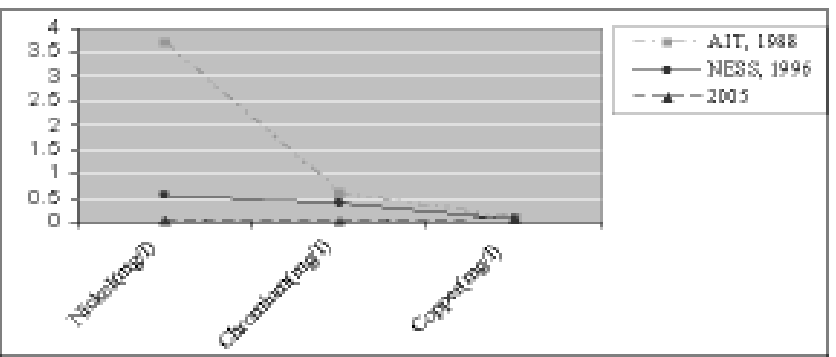

Fig 4: Comparison of metals in leachate

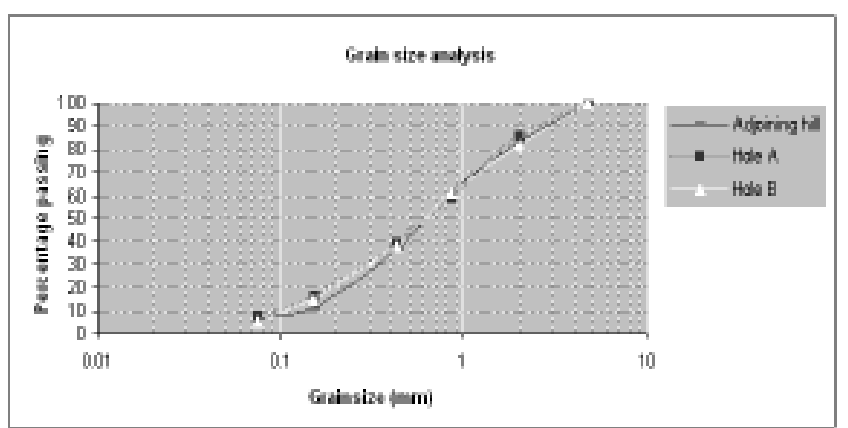

Fig 5: Grain size analyses of samples collected from adjoining hill and holes A and B.

Table 5 estimates the economic price of landfill gas with replacement cost of liquefied petroleum gas (LPG) used for cooking purpose.

Figure 5 shows the grain size analysis of soil samples from the two holes and the adjoining hill. In table 6 chemical analyses of the soil samples are presented.

The fine grained silty sand of the soils in the holes A and B and the adjoining hills may justify the fact that the materials from the adjoining hills were used to cover the waste. A large fraction of organic matter indicates that the waste is well degraded in GLFS. High percentage of organic matter, Nitrogen and other parameters in samples from the holes than those of sample from the adjoining hill may indicate that the impact of landfilling is pronounced in the site, however it needs further justification.

\subsection{GLFS Project Activities}

Table 7 shows the monitoring of gas, leachate/groundwater and waste during operation of GLFS. In table 8 modes of public participation and economic measures to minimize public opposition are presented. Compensatory measures provided by GLFS and local people's perception about public participation are listed in tables 9 and 10 respectively.

Table 5: Estimation of economic price of landfill gas.

\begin{tabular}{|c|l|l|}
\hline 1 & Total duration of landfill gas used & 43 months (June 2001-January 2005) \\
\hline 2 & Estimated use of LPG use after stoppage of landfill gas & 1 cylinder 1.5 months $=0.66$ cylinder per month \\
\hline 3 & Estimated LPG use for 43 months & $0.66 \mathrm{X} 43$ cylinders \\
\hline 4 & Price of LPG as 2005 & $\mathrm{Rs} 900$ per cylinder \\
\hline 5 & $\begin{array}{l}\text { Economic price of landfill gas with replacement cost of } \\
\text { LPG as per usage for cooking pupose }\end{array}$ & $\mathrm{Rs} 0.66 \mathrm{X} 43 \mathrm{X} 900=\mathrm{Rs} 25,542$ \\
\hline
\end{tabular}

Table 6: Results from the chemical analysis of soil from GLFS.

\begin{tabular}{|c|l|c|c|c|}
\hline \multirow{2}{*}{ S.No. Parameters } & \multicolumn{3}{|c|}{ Soil Sample } \\
\cline { 3 - 5 } & & Hole A & Hole B & Adjoining Hill \\
\hline 1 & Total Nitrogen $(\mathrm{mg} / \mathrm{g})$ & 13.9 & 14.3 & 9.9 \\
\hline 2 & Total Phosphorous $(\mu \mathrm{g} / \mathrm{g})$ & 2.1 & 5.8 & 4.2 \\
\hline 3 & Potassium $(\mathrm{mg} / \mathrm{g})$ & 5.0 & 6.66 & 4.34 \\
\hline 4 & Organic Matter $(\%)$ & 55.52 & 72.49 & 37.9 \\
\hline 5 & Calcium $(\mathrm{mg} / \mathrm{g})$ & 20.83 & 12.85 & 9.65 \\
\hline 6 & Magnesium $(\mathrm{mg} / \mathrm{g})$ & 5.0 & 2.33 & 1.83 \\
\hline
\end{tabular}


Table 7: Monitoring parameters during operation of GLFS.

\begin{tabular}{|l|l|l|l|}
\hline \multicolumn{1}{|c|}{ Monitoring factor } & \multicolumn{1}{|c|}{ Goal } & \multicolumn{1}{c|}{ Monitoring system } & \multicolumn{1}{c|}{ Frequency } \\
\hline Gas/Air & No provision & No provision & No provision \\
\hline $\begin{array}{l}\text { Leachate } \\
\text { groundwater }\end{array}$ & $\begin{array}{l}\text { Risk of groundwater/Surface } \\
\text { water pollution due to leachate }\end{array}$ & $\begin{array}{l}\text { Laboratory analysis through } \\
\text { consultants }\end{array}$ & $\begin{array}{l}\text { Was not performed } \\
\text { with regular frequency }\end{array}$ \\
\hline Waste & $\begin{array}{l}\text { Segregation of hazardons } \\
\text { wastes }\end{array}$ & $\begin{array}{l}\text { Simple counting of trucks; special } \\
\text { waste dumped in separate site } \\
\text { within GLFS }\end{array}$ & Daily \\
\hline
\end{tabular}

*Environmental factors as defined according to the Vaxjo risk assessment model (Nilson and Hutt, 1990)

The table is based on the interview with the then site-in- charge of GLFS.

Table 8: Measures adopted by GLFS to minimize NIMBY opposition during operation.

\begin{tabular}{|l|l|l|}
\hline $\begin{array}{c}\text { Measures applied to } \\
\text { minimize NIMBY opposition }\end{array}$ & \multicolumn{1}{|c|}{ Type of measures applied ${ }^{* *}$} & \multicolumn{1}{c|}{ Remarks $^{* * *}$} \\
\hline Public Participation & $\begin{array}{l}\text { Involvement of the then Village } \\
\text { Chief prior to the implementation of } \\
\text { GLFS } \\
\text { Monitoring group formed from local } \\
\text { people of the adjoining settlement }\end{array}$ & $\begin{array}{l}\text { Effectiveness in dumping the waste inside } \\
\text { GLFS increased after formation of monitoring } \\
\text { group but after the members weren't serious of } \\
\text { their duties and they were selected with } \\
\text { political influence. }\end{array}$ \\
\hline Economic Measures & Compensation works & $\begin{array}{l}\text { Compensations not effectively distributed in } \\
\text { response to the effect from GLFS. }\end{array}$ \\
\hline Source: ${ }^{* *}$ Key Informants Survey, ${ }^{* * *}$ Household Survey, 2005.
\end{tabular}

\section{DISCUSSIONS AND CONCLUSION}

This paper contains an assessment of GLFS considering some monitoring factors and some issues during landfill management. Although environmental management requires comprehensive resource inventories and evaluation, preliminary conclusions can be drawn to assess the postoperation risk of GLFS, various measures adopted by GLFS during the operation phase and possibility of the monitoring approach in environmental policy making.

\subsection{Post project Impact Assessment of GLFS}

If we look at the results in terms of environmental impacts, we can see that GLFS may constitute concrete environmental conflict, even after final operation. While the landfill has a visible impact to the landscape since the entire valley is filled with waste, excavation of the waste showed the presence of hazardous or industrial waste couldn't be excluded. Laboratory analysis of leachate compares it with heavily polluted waste water. And since there is no liner laid and the area that could be affected is not well defined, there is risk of pollution of ground water due to leachate. Soil analysis confirmed that the fact that the material from the adjoining hill was used to cover the waste. Higher level of chemical parameters in the soil samples from the landfilled area than that of from adjoining hill showed that impact of landfilling is pronounced in the area. It was observed that in the leachate sample, $\mathrm{P}^{\mathrm{H}}$ values was above 7 (i.e. 7.2) and has increased from that of NESS, 1996 and BOD and COD values decreased from NESS, 1996. This shows good biodegradation (i.e. stable methane process $)^{8}$ is going in the site and it poses a risk of migration and explosion of $\mathrm{CH}^{-}$gas since there is no gas control at GLFS.

The environmental inventory at GLFS shows necessity of some protective measures necessary to the surrounding groundwater against contamination with leachate and some preventory measures against the risk of migration and explosion of gas.

\subsection{GLFS Project Activities}

If we regard the activities performed by GLFS project, we can see inadequate compliance with the planning and operational strategies, which is also a major issue environmentally. Monitoring activities - as in the case of waste, leachate/ groundwater, gas - were unsatisfactory. Other factors such as public involvement and economic measures were dealt only after public opposition started. However, GLFS was able to extend the landfilling, after it included local people in monitoring activities, and compensated as per local people's need.

GLFS could contribute to an integrated waste management approach by opening a compost plant or collecting recyclable/ reusable materials prior to landfilling which in turn would have helped to increase the life of the landfill site. Besides recycling and composting, tapping of methane gas (refer estimation of economic price of landfill gas) could help in collecting fund for the landfill site.

$8 \quad$ According to Oeltzschner and Kharel (1997), from other landfill sites, if the stable methane process (i.e. good biodegradation) is going on, the $\mathrm{P}^{\mathrm{H}}$ value should be higher than 7 and BOD as well as COD should have gone down. 
Table 9: Compensation work provided by GLFS project during operation phase.

\begin{tabular}{|l|c|l|}
\hline VDCs & Ward nos. & Compensation work provided \\
\hline Mulpani & 1 & Somtirtha Temple, Construction of Gita Temple and paving of stone at Somtirtha. \\
\hline & 2 & Radhakrishna Temple, Library building. \\
\hline & 3 & Ananda Bhairab Primary School building, Bambuko Youth Club building \\
\hline & 4 & $\begin{array}{l}\text { Road construction, Drainage by the side of stream passing through ward nos. 3, 4, 5, side drain } \\
\text { before VDC office building. }\end{array}$ \\
\hline & 5 & Drainage, Black topped road from Milan Chowk to Gothatar VDC border. \\
\hline & 6 & Neo-progress Club building, Nepal Rastriya Nirman Secondary School building \\
\hline & 7 & Water tank (not used today). \\
\hline & 8 & $\begin{array}{l}\text { Water supply from Sundarijal, Drain wall at Dahal Gaon, Panchayan Temple, Tiwari Tole } \\
\text { drainage, Sukumbaski Tole drainage, Retaining wall at Tiwari Tole, Nagdaha library building, } \\
\text { Gravel road and Gabion wall at Baikuntha Tapu, Retaining wall at the road from Mulpani-8 to } \\
\text { Patale Chaur. }\end{array}$ \\
\hline & 9 & Road constructin, culvert, drainage, Hospital buildings, Ambulance to the VDC. \\
\hline Jorpati & 5 & Club building, drainage, gabion walls, water supply. \\
\hline
\end{tabular}

Source: Field Survey, 2005.

Table 10: Local's perception about Public Involvement.

\begin{tabular}{|c|l|c|c|c|}
\hline S.No. & Statement & Agree (\%) & Disagree (\%) & Not informed (\%) \\
\hline 1 & $\begin{array}{l}\text { Public were informed about the GLFS during its } \\
\text { design phase }\end{array}$ & 77.50 & 12.50 \\
\hline 2 & $\begin{array}{l}\text { Information of activities were disseminated to the } \\
\text { public during the implementation phase }\end{array}$ & 5.00 & 12.50 \\
\hline 3 & $\begin{array}{l}\text { Public suggestions were implemented by the authority } \\
\text { to reduce the public opposition. }\end{array}$ & 12.50 & 80.00 & 7.50 \\
\hline 4 & $\begin{array}{l}\text { Public involvement is necessary in the project within } \\
\text { their vicinity }\end{array}$ & 67.50 & 27.50 & 5.00 \\
\hline
\end{tabular}

Source: Questionnaire Survey, 2005.

Total number of locals surveyed $=40$.

\subsection{Possibility of using the post project monitoring approach in environmental policy making}

If we compare the measurement of environmental variables (e.g. groundwater and soil) during and after operation, we may interpret that they may have occurred as a result of the project. Although it requires establishment of casual relationships between action and effect through 'reference' and 'treatment' monitoring stations, this type of information may be used to define the monitoring system in terms of impacts to be monitored.

Other information, such as response to impacts (e.g. using agencies' authorities to reduce and prevent impacts) and their effectiveness in reducing impacts determine the implementation of monitoring system. Hence, it could be concluded that monitoring might be viewed within the adaptive and lifecycle process nature of environmental management goals and may be valuable for environmental policy formulation.

\subsection{General Conclusion:}

Environmental monitoring and assessment appear to be a useful approach for environmental management program; environmental protection measures to eliminate the risk to the surroundings and local people's health could also be generated. Similarly taking some monitoring parameters and effectiveness of some activities during project, a systemic method using minimum of resources and still generating effective environmental protective measures may be created.

\section{ACKNOWLEDGEMENTS}

This paper is the modified version of the author's M. Sc. Thesis which was partially funded by the Ministry of Environment, Science and Technology (MoEST). Suggestions from Prof. Dr. Umakanta Ray Yadav, Head, Central Department of Environmental Science, Tribhuvan University, and Mr. Narendra Prasad Pokhrel, Senior Divisional Chemist, MoEST during the work are highly appreciated.

\section{REFERENCES}

AIT. 1988., as cited in Oeltzschner, H. and Kharel, B.D. 1997. Hydrological and Geological Aspects of the Final Operation, Closure and Restoration of Gokarna Landfill Site, Kathmandu. Report prepared on the behalf of Federal Institute of Geosciences and Natural Resources, Hannover, and German Advisory team in Nepal, Department of Mines and Geology, Kathmandu. 
ASTM standards. 1986. Annual Book of ASTM standard's: Section-4. American Society for Testing and Material, Philadelphia.

APHA. 1998. Standard methods for the Examination of Water and Wastewater. (20 th edition). American Public Health Association, American Water Works Association and Water Environment Federation, USA.

Dhaubhadel. 1988., as cited in Oeltzschner, H. and Kharel, B.D. 1997. Hydrological and Geological Aspects of the Final Operation, Closure and Restoration of Gokarna Landfill Site, Kathmandu. Report prepared on the behalf of Federal Institute of Geosciences and Natural Resources, Hannover, and German Advisory team in Nepal, Department of Mines and Geology, Kathmandu.

Economic Commission for Europe (ECE). 1990., as cited in Shepherd, A. 1994. Post Project Impact Assessment and Monitoring. Environmental Methods Review: Retooling Impact Assessment for the New Century, (eds.) Alan L. Porter and John J. Fittipalai. The Press Club, North Dakota, 1998. 164-170.

GTZ. 1996. Solid Waste Management in Nepal. Report on the Fact Finding Mission for the Project PN 93.2203.3-01.100 prepared on the behalf of the GTZ GmbH, May 1996.

Hogland, W. 1989., as cited in Christina A. and Veronica, B. 2004. Solid Waste Management in the City of Kathamandu, Nepal, Evaluation of the Vaxjo Risk Assessment Model Applied on Gokarna Landfill Site. B.Sc. Thesis, Department of Technology, University of Kalmar, Sweden.

Khadka, R.B. (ed.). 1996. EIA Training Manual for Professionals and Managers. Asian Regional Environmental Assessment Programme, IUCN Nepal, Kathmandu.

Lohani, B., Evans, J.W., Ludwig, H., Everitt, R.R., Carpenter, Richard A. and Tu, S.L. 1997. Environmental Impact Assessment for Developing Countries in Asia, Vol. 1-Overview. 364.

Munn, R.E., Riviere, J.W.M. la and Campagne, N. van Lookeren. 1996. Policy Making in an Era of Global Environmental Change. Kluwer Academic Publishers, Dordrecht. pp 97-112.

NESS. 1996. Environmental Management Plan of the Gokarna Landfill Site, Kathmandu, Preparation of Base Map and Monitoring of the Leachate, Surface and Sub-surface Waters. Report submitted to Solid Waste Management and Resource Mobilization Center, Kathmandu.
Nilson, S. and Hult, J. 1990., as cited in Christina A. and Veronica, B. 2004. Solid Waste Management in the City of Kathamandu, Nepal, Evaluation of the Vaxjo Risk Assessment Model Applied on Gokarna Landfill Site. B.Sc. Thesis, Department of Technology, University of Kalmar, Sweden.

Oeltzschner, H. and Mutz, D. 1994. Guidelines for an Appropriate Management of Domestic Sanitary Landfill Sites. GTZ.

Oeltzschner, H. and Kharel, B.D. 1997. Hydrological and Geological Aspects of the Final Operation, Closure and Restoration of Gokarna Landfill Site, Kathmandu. Report prepared on the behalf of Federal Institute of Geosciences and Natural Resources, Hannover, and German Advisory team in Nepal, Department of Mines and Geology, Kathmandu.

Quah, E. and Tan, Khye Chong. 1996. The Siting Problem of Nimby Facilities: Cost Benefit and Auction Mechanism, Jakarta Conference Paper. http://www.igcc.ucsd.edu/igcc2/pub/pibsonline/ environment/seasiantrade-environmen96/quahtan.html.

Radetzki, M. 1992., as cited in Jayadevappa, R. and Chhatre, S. 2000. International Trade and Environmental Quality: A Survey. Ecological Economics. 32(2): 175-194.

Rothman, D.H. 1998. Environmental Kuznets Curves - Real Progress or Passing the Buck? A Case for Consumption Approaches. Ecological Economics. 25(2): 177-194.

Rushbrook, P. 1985. Solid Waste Landfills in Middle- and LowerIncome Countries: A Technical Guide to Planning, Design and Implementation, and Operation. World Bank Technical Paper; No. 426.

Shafik, N. 1994. Economic Development and Environmental Quality: An Economic Analysis. Oxford Econ. Papers. 46: 757-773.

Shepherd, A. 1994. Post Project Impact Assessment and Monitoring. Environmental Methods Review: Retooling Impact Assessment for the New Century, (eds.) Alan L. Porter and John J. Fittipalai. The Press Club, North Dakota, 1998. pp 164-170.

Shields, P.A. 1990. Communicate and Listen: Best Defense against NIMBY. The Management of World Wastes: The Interdependent Voice of Industry. Feb. 1990. 33(2): 33-34.

Trivedy, R.K. and Goel, P.K. 1984. Chemical and Biological Methods for Water Pollution Studies. Environmental Publication, Karad, 415110, India. 